\title{
FUNCTIONAL EGG PRODUCTION. II. THE ROLES OF SELENIUM, ZINC, AND IODINE
} (review)

\section{A.Sh. KAVTARASHVILI, I.L. STEFANOVA, V.S. SVITKIN, E.N. NOVOTOROV}

Federal Scientific Center All-Russian Research and Technological Poultry Institute RAS, Federal Agency of Scientific Organizations, 10, ul. Ptitsegradskaya, Sergiev Posad, Moscow Province, 141311 Russia, e-mail alexk@vnitip.ru (corresponding author),dp.vniipp@mail.ru,89267796966@yandex.ru, en-5506040@mail.ru ORCID:

Kavtarashvili A.Sh. orcid.org/0000-0001-9108-1632 Stefanova I.L. orcid.org/0000-0002-4394-5149

Svitkin V.S. orcid.org/0000-0002-4161-0986

The authors declare no conflict of interests Acknowledgements:

Supported by the grant from Russian Science Foundation under project 16-16-04047 for the development of functional egg products enriched with essential nutrients, optimal metabolic parameters and low allergenicity Received May 14, 2017

\section{Abstract}

Different aspects of selenium, zinc, and iodine in the nutrition of laying hens are reviewed in relation to the production of functional eggs enriched with these trace elements. Selenium can be easily transferred into the eggs. Selenium is a part of certain antioxidant selenoproteins (primarily enzyme glutathione-peroxidase) improving antioxidant status and the system of antiradical defense in laying hens; these compounds can also be transferred into eggs improving the oxidative stability of yolk and albumen during egg storage (Z.G. Wang et al., 2010). Recent results of the worldwide research proved that diets for layers (and eggs as a result) should by advisably enriched simultaneously with selenium (M. Fasiangova, G. Borilova, 2017) and vitamin E since this combination of the two most active dietary antioxidants provides the best antioxidative defense in layers and the best antioxidative status of the eggs (Z. Zduńczyk et al., 2013). The organic forms of selenium are shown to be the most effective selenium sources (compared to inorganic sources) due to less toxicity for poultry, better selenium transfer to eggs and deposition into the body selenium pool, primarily in muscle tissues, which can be activated during an oxidative stress (P.F. Surai, V.I. Fisinin, 2016). The combination was also shown to be an effective protector for polyunsaturated fatty acids in yolk lipids (A.Sh. Kavtarashvili et al., 2017). Determination of optimal proportion of selenium and vitamin E in diets for layers requires further research and justification. Zinc is an integral part of antioxidative enzyme superoxide-dismutase (SOD) and lowers oxidative stresses due to the antagonism to the ions of transition metals with high redox potentials. Enrichment of eggs with zinc via high dietary zinc levels improves quality and stability of the albumen during egg storage (H. Aliarabi et al., 2007), eggshell quality, bone development, feather condition and immunity in layers (K.M. Martin, 2016). Supplementation of diets for layers with 50-80 ppm of inorganic or 500-100 ppm of organic zinc will generally not affect their productivity (K. Sahin et al., 2009). Simultaneous enrichment of eggs with selenium and zinc using their high dietary levels is complicated by the antagonism between the two elements which will be possibly overcome due to the development and investigation of their new dietary forms and sources. High dietary iodine levels provide the possibility for the production of iodine-enriched functional eggs; according to EU legislation, however, iodine level in diets of laying birds should not surpass $5 \mathrm{ppm}$ (EU Commission, 2005). Several studies reported the absence of detrimental effects of higher dietary iodine doses $(5-10 \mathrm{ppm})$ on overall productivity in layers while certain egg quality parameters (eggshell thickness and strength, relative albumen weight, Haugh units) decreased with the increase in dietary iodine content (M. Lichovnikova, L. Zeman, M. Cermakova, 2003). Simultaneous enrichment of eggs with selenium and iodine is possible (Yu.A. Ponomarenko, 2015) since these two elements are not antagonists (especially in their organic forms) but rather synergists; the efficiency of different sources and doses of selenium and iodine in combined diet supplementation and transfer to eggs is still to be elucidated.

Keywords: functional eggs, laying hens, selenium, zinc, iodine, dietary levels and sources, egg composition and quality

In the previous part of our review we considered the issues related to the 
content of polyunsaturated fatty acids (PUFA) of the $\omega-3$ series in chicken eggs, and also showed the need for their additional enrichment with antioxidants on the example of vitamin E [1]. Another important field in the production of functional eggs is their enrichment with trace elements that are deficit in human nutrition. Some trace elements that show antioxidant properties increase antioxidant capacity and add value to eggs as a functional food product. These elements are successfully transferred into eggs via the layers diets. Complex enrichment of eggs with target trace elements is also possible. However, the interaction of these elements may cause certain problems.

This paper is the first to comprehensively summarize various aspects of eggs enrichment with trace elements possessing antioxidant properties ( $\mathrm{Se}, \mathrm{Zn}$ and I) separately and jointly.

Sele nium. Se is one of the most significant antioxidant trace elements for humans and animals [2]. High doses of Se are toxic, but its natural content and rates of additional uptake in feeds are usually 10-20 times lower than dangerous ones [3]. Selenium can be incorporated into proteins, replacing sulfur atoms in sulfur-containing amino acids (in particular, in methionine and cysteine) forming selenoproteins (SeP). In addition, plant SeP contain predominant selenomethionine (SeMet), while animal SeP contain selenocysteine (SeCys). SeMet in vertebrates does not show neither any coding triplets, nor transfer RNA [4], while SeCys has UGA coding triplet [5]. Selenoproteins are an essential part of a proteome. The chickens have about $25 \mathrm{SeP}$ genes the expression of which affects the regulation of cell growth and apoptosis, as well as functions of cellular signaling systems and transcription factors [6].

Some SeP (the family of glutathione peroxidases - GP, thioredoxin reductases, etc.) are antioxidant enzymes, the SeCys fragment [7] being the site of their activity. GP are the most significant in the system of protecting tissue damage from free radicals. One of the GP form is found in the gastrointestinal tract. It suppresses the absorption of hydroperoxides [8]. Phospholipid GP is a part of the lipid fraction of membranes and inhibits lipid peroxydation, protecting the structural integrity of membranes [9]. In eggs, Se, particularly GP, protects against peroroxydation of yolk lipids and albumen [10-12].

Formerly, it was considered that the laying hens have low need in selenium $(0.06 \mathrm{mg} / \mathrm{kg}$ of feed $)$, but later it was found that requirement in this element rapidly increases due to stress, particularly in case of intensive husbandry technology [13]. It was also reported that Se preparations can mitigate the harmful effects of feeds contamination with mycotoxin by improving anti-radical protection of the organism [14]. Selenium deficiency (hyposelenosis) causes exudative diathesis [15], food-related encephalomalacia [16], food-related pancreas atrophy [17] in poultry. The combination of Se and vitamin E deficiencies are especially dangerous. Se excess is also toxic to poultry: food-related hyperselenosis manifests itself in the inhibition of growth and egg productivity, anemia, decreased mobility of the tibiotarsal joints [18] and the relative weigh of heart and liver [19], degeneration and/or necrosis of the liver, myocardial degeneration, and necrosis of the convoluted kidney tubules [20]. Thus, the amount of Se in the diet should be optimal, so as not to reduce the productivity and viability of poultry. The literature indicates different $\mathrm{LD}_{50}$ of Se: $9.7 \mathrm{mg} / \mathrm{kg}$ of live weight (selenite, per oral) for hens [21]; $24.6 \mathrm{mg} / \mathrm{kg}$ with a low toxic dose of $1.7 \mathrm{mg} / \mathrm{kg}$ for chickens [22]; $33.4 \mathrm{mg} / \mathrm{kg}$ with a low toxic dose for laying hens being 15 $\mathrm{mg} / \mathrm{kg}$ [23].

Three main reasons for enriching the laying hens' diets with Se [13] are maintaining their health and productivity, including the condition of skeleton [24], achieving optimal quality of albumen, yolk and eggshell, and selenium 
providing to egg consumers. Formerly, selenium was introduced into animal diets only in inorganic forms in the form of selenite $\left(\mathrm{Se}^{+4}\right)$, selenate $\left(\mathrm{Se}^{+6}\right)$ and selenide $\left(\mathrm{Se}^{-2}\right)$. Later, the organic forms appeared. Among the inorganic sources of Se, selenate and sodium selenite are now the most common. In poultry diets selenite has two important advantages: it is much cheaper that all organic sources and is metabolized quickly, which allows an organism to make an accelerated synthesis of selenoproteins at the Se deficiency [3]. The disadvantages of inorganic forms of selenium are relatively high toxicity, Se interaction with other trace elements, low incorporation into muscles, and low efficiency of its transfer into eggs [13]. Moreover, selenite (especially in high doses) shows pro-oxidant activity [25]. SeMet is the most common among the organic preparations. Apart from the two main selenated amino acids, hydroxy-selenomethionine (as a more persistent and stable analogue of SeMet) [13], and selenium homolanthionine [26] were studied as another source of Se. Selenated yeast and algae (chlorella) were also used, where Se was found mainly in the form of SeMet. Organic preparations of Se diacetophenonyl selenide, or bis-(benzoylmethyl)-selenide (DAFS-25), and 9-phenyl-sym octahydro selenoxanthene (selenopyran) have been developed and are being used in Russia. Se nanopreparations ensure more precise delivery of the element to the target organs and tissues and have a low toxicity, which increases the bioavailability and effectiveness of Se application [27-29].

Prior comparative studies on various sources of Se led to the conclusion that inorganic sources are preferred to the organic ones for they are better metabolized by the organism and more efficiently fit into SeCys, synthesized in the liver from serine and $\mathrm{H}_{2} \mathrm{Se}$ [30]. Some authors still claim that feed organic preparations of selenium for inclusion in an organism's proteins require preliminary metabolization of $\mathrm{Se}$ in $\mathrm{H}_{2} \mathrm{Se}$, therefore they do not have advantages over inorganic forms both in the efficiency of selenium absorption and use, and in toxicity [31]. However, this is not exactly right. Indeed, the exogenous SeCys do not fit into the functional endogenous selenoproteins (such as GP), which is proved by the work with preparations labeled with ${ }^{75} \mathrm{Se}$ [32]. However, SeMet is not recognized by the mammal's intestine as a selenium-containing substance, therefore it is absorbed and used in the body similarly to methionine [33], that is, with very high speed and efficiency (most likely exceeding that in case of passive absorption of Se from inorganic sources). Absorbed SeMet is nonspecifically fit into various structural and non-functional proteins (for example, into muscle proteins that accumulate half of all selenium reserves in a mammal organism), creating a Se repository. It is mobilized in case of stress or other conditions, when the body's need for metabolically active selenium increases.

A similar mechanism of active absorption and incorporation into proteins is shown for feed SeCys, though to a lesser extent. Probably, the organism partially recognizes it as a source of Se and metabolizes it on the "inorganic way". A study of selenium tissues distribution in chickens during the feeding of selenated yeast showed [34] that in the muscles the SeMet content had truly and significantly increased, while it was SeCys content that increased in liver and kidneys. The amount of SeMet increased in all organs and tissues with the dose of organic Se, whereas when selenium was fed, this effect was much less pronounced, and an increase in the CeCys content was seen in the heart tissues only. Inorganic forms of selenium (unlike the organic ones) cannot participate in the creation of the Se repository, since the non-metabolized residue of inorganic $\mathrm{Se}$ is rapidly excreted renally [35]. As for the relative toxicity of inorganic and organic forms of Se, DAFS-25 (rats, orally), for example, shows the toxicity that is 20 times lower than that of sodium selenite [36]. 
Another important aspect of selenium feed of the poultry is this element's interaction with vitamin E. Se-dependent enzyme thioredoxin-reductase is involved in the reduction of oxidized forms of vitamin E, into which it is converted through the neutralization of free peroxide radicals in biological membranes [37]. Thus, both antioxidants work both separately and together in the anti-radical protection system. It is no wonder that plenty of research dealt with seeking their optimal correlation in poultry diets in recent years. Enriching diets with organic forms of Se allows reducing the amount of expensive vitamin $\mathrm{E}$ added to the diet by $25-30 \%$ [38].

It has also been reported that the inclusion of Se in laying hen diets increases the vitamin E content in egg yolk [39]. This index made respectively 297, 311 and $370-375 \mathrm{mg} / \mathrm{kg}$ of dry yolk solids without addition of Se and in the groups receiving selenite and Se-enriched yeast or algae. Therefore, in the interaction between vitamin $\mathrm{E}$ and $\mathrm{Se}$, organic forms of selenium are more efficient. When selenite was fed to lambs, the content of vitamin E in their liver decreased if compared with the control group (without the addition of Se), and the highest doses of Se (3-4 mg/kg of body weight), the decrease was proved $(\mathrm{p}<0.01)$. After feeding SeMet, a significant but not proved decrease in the amount of vitamin $\mathrm{E}$ in liver was observed only at the highest dose of Se ( $8 \mathrm{mg} / \mathrm{kg}$ of body weight) [40]. An increase in the dose of Se and vitamin E in hens' diets raised the antioxidant blood status [41] and improved liver function, statistically $(\mathrm{p}<0.05)$ decreasing the concentration of bilirubin, aspartate aminotransferase and alanine aminotransferase in blood plasma [42]. The immune status of layers also improved: the amount of immunoglobulin IgA in the blood [41] and the antibody titer against the Newcastle disease virus [42] increased.

Some authors believe [31] that so far there is no firm evidence of the advantages of organic forms of Se over inorganic ones in their effect on the productivity of animals. However, numerous studies show that organic forms more effectively improve the selenium and antioxidant status, health, egg and meat poultry productivities, and the quality of eggs and other poultry products. Thus, when comparing the effects of selenite, Se-yeast and DL-SeMet, it was found that in the same doses $(0.3 \mathrm{mg} \mathrm{Se} / \mathrm{kg}$ of feed) both organic forms more effectively increased the activity of GP and the amount of Se in the albumen ( $p<0.01)$, pectorals and leg muscles of laying hens $(p<0.001)$ than the inorganic form [43]. Interestingly, the Se accumulation in the albumen and muscle protein in case of feeding DL-SeMet was significantly higher than when feeding Se-yeast $(p<0.05)$. Se deposition in the yolk was not significantly different between the organic forms. With the increase in the amount of SeMet introduced into the diet (apart from selenite), the Se content in albumen increased [44].

Among other parameters that are possibly affected by the enrichment of the layers diet with selenium, are the $\mathrm{pH}$ of the egg contents, the fatty acid profile of the yolk lipids [45], and the oxidation stability of the yolk and albumen [46]. Eggs enrichment with Se increases their resistance to internal oxidation processes during storage. The slower the $\mathrm{pH}$ grows inside the egg, the better its quality is maintained. This slowdown in case of layers diets enrichment with Se and with vitamin $\mathrm{E}$ at the same time is accompanied by an increase in the strength of the vitelline membrane and/or the putamen [47]. Improvement in the preservation of the yolk oxycarotenoid pigments in eggs was also reported: feeding Se-yeast to laying hens resulted in a significant increase in the yolk color grade on the Hoffmann-La Roche scale from 4.77 in the control to 5.04 [48]. The slowing down of yolk and albumen oxidative products accumulation in eggs after introducing Se into the diets of laying hens is usually associated with an increase in the activity of GP. Both organic and inorganic forms of Se influ- 
enced the concentration of malondialdehyde (MDA) in fresh and stored eggs, however inorganic selenium was less effective after long storage periods [49]. Feeding Se (in $0.3 \mathrm{mg} / \mathrm{kg}$ ) in the form of Se-yeast significantly reduced the concentration of MDA in the yolk compared to the control (without feeding selenium) [12]. Concentration of carbonyl compounds in albumen also decreased, making 4.55 and $4.43 \mathrm{nmol} / \mathrm{mg}$ of 2,4-dinitrophenylhydrazine with doses of Se of 0.3 and $0.6 \mathrm{~g} / \mathrm{t}$ respectively (control: $4.67 \mathrm{nmol} / \mathrm{mg}$ ).

$\mathrm{Zinc}$. $\mathrm{Zn}$ is part of and/or mediates the activity of several hundred enzymes [50], including carbonic anhydrase, which provides carbonate anions to form eggshell [51]. $\mathrm{Zn}$ is necessary for antioxidant protection as one of the cofactors of superoxide dismutase (SOD) that converts superoxide anions to hydrogen peroxide [52]. It also reduces oxidative stress by being an antagonist of ions of transition metals with a high redox (inorganic copper and iron), preventing the formation of hydroxyl radicals from hydrogen peroxide. In the Fenton reaction, $\mathrm{Zn}$ competes with other transition metals $(\mathrm{Cu}$ and $\mathrm{Fe})$ beyond the binding locations and serves as an electron donor for these reactions [53-55]. The acute antioxidant effect of zinc is related to its antagonism to other transition metals and the protection of sulfhydryl groups of proteins. The chronic effect manifests itself in protection from prooxidants through participating in the synthesis or activation of other antioxidants, for example metallothioneins. Metallothioneins are cysteine-rich proteins. They include the $\mathrm{Zn}$-dependent ones, which are capable of neutralizing oxygen radicals [56] and binding divalent metal cations, regulating their homeostasis [57].

Zinc deficiency in the diets of young animals causes abnormalities and defects in bone development, poor bone mineralization, growth retardation, coat deterioration and dysfunction of immune system [57]. High content of this element worsens the mineralization of the skeleton due to impaired absorption and use of $\mathrm{Ca}$ and $\mathrm{P}$ [58]. Most likely, this effect is related to the competition between trace elements for inhausting sites in the digestive tract of birds. Superhigh doses of $\mathrm{Zn}(\sim 10-20 \mathrm{~g} / \mathrm{t}$ of feed) cause pancreatic and muscular stomach cankering in birds [59]. Another negative consequence of high doses of $\mathrm{Zn}$ is an increase in its excretion and quantity in litter. Since plants poorly accumulate $\mathrm{Zn}$, it can reduce soil fertility [60]. At the same time, an increase in nitrogen retention was reported in response to the $\mathrm{Zn}$ introduction into the diets. $\mathrm{Zn}$ inhibits the microbial enzyme uric acid-degrading uricase [61].

Formerly, zinc was added to poultry diets in the form of inorganic sulphate or oxide. The National Research Council (NRC, USA) [62)] establishes the following standard rate of $\mathrm{Zn}$ in the diets of egg-producing poultry: $38-40 \mathrm{~g} / \mathrm{t}$ for the young, 33-35 mg/t for adults, whereby the requirement of brown crosses is slightly lower than that of white ones. Later, they used organic forms of $\mathrm{Zn}$, mostly chelate compounds with different amino acids (most often with methionine), small peptides and proteins, and picolinic acid (pyridine-2-carboxylic). Availability of feed zinc depends on the composition of the diet, for example, the content of phytates (inositol-polyphosphates). The latter include some that are able to firmly chelate $\mathrm{Zn}$. Adding phytase to a diet rich in phytate increases the bioavailability of $\mathrm{Zn}$, feed intake and the increase in body weight of broilers [63]. Other divalent metals competing with $\mathrm{Zn}$ for inhausting sites and carrier molecules can also affect the availability of feed $\mathrm{Zn} \mathrm{[64].} \mathrm{For} \mathrm{broilers,} \mathrm{the} \mathrm{bioa-}$ vailability of the $\mathrm{Zn}$ with amino acids complex was $64 \%$ higher than that of zinc sulfate, while the poultry that received the organic form showed improved feed conversion [65]. Similar results were obtained by N.M. Salim with contributing authors [66]. However, some studies almost did not make any difference between the bioavailabilities of organic and inorganic $\mathrm{Zn}$ [67]. A number of studies 
stated that the bioavailability of $\mathrm{Zn}$ from different preparations can be evaluated by its solubility in a buffer with $\mathrm{pH} 5.0$ [68], where $\mathrm{Zn}$ proteinate sample showed better bioavailability of $\mathrm{Zn}$. The positive effect of combined use of organic and inorganic $\mathrm{Zn}$ is shown. Since zinc is absorbed in the small intestine both passively (diffusion) and with the involvement of proteins that perform the transmembrane transport of divalent cations, the simultaneous presence of two forms of $\mathrm{Zn}$ in the chyme allows using different absorption mechanisms in case of competition or inhibition of one of them [69, 70]. Comparing the two doses of $\mathrm{Zn}$ ( 25 and $50 \mathrm{~g} / \mathrm{t}$ ) in the form of sulfate and organic preparation in layers it was established that neither the dose nor the form of $\mathrm{Zn}$ influenced egg production capacity, egg weight and feed conversion. However, both forms increased the height of albumen and the Haugh index [71].

It is known that in adult egg laying poultry the amount of zinc in the diet is related to the quality of the eggshell and the bone structure (osteoporosis), the latter being especially important for the cage housing of layersdue to the syndrome of cellular fatigue. The recent study that used different forms of zinc and other trace elements [72] pointed out that the strength and specific gravity of eggshells showed proved linear increase $(p<0.05)$ with an increase in the amount of $\mathrm{Zn}$ in the diet (from 30 to $120 \mathrm{~g} / \mathrm{t}$ ). The egg breakage rate decreased. The authors attribute the eggshell quality to an increase in the density of the palisade layer and a decrease in the density of the mamillary layer. Laying hens that received $\mathrm{Zn}$ in doses from 0 to $80 \mathrm{~g} / \mathrm{t}$ in the form of sulfate or chelate with hydroxy methionine showed that the organic form caused better confirmed improvement $(\mathrm{p}<0.05)$ of the thickness and strength of the eggshell, the strength of the tibia, as well as the titer of antibodies against sheep erythrocytes [73]. Egyptian researchers [74] studied the possibility of producing zinc-enriched eggs in the chickens of the local breed Golden Montazah, feeding it in the form of sulfate or chelate with methionine $(0,50,100$, and $150 \mathrm{~g} / \mathrm{t})$. At the maximum studied dose of $\mathrm{ZnMet}$, the highest concentration of $\mathrm{Zn}$ in eggs was recorded $(2.23 \mathrm{mg} / 100 \mathrm{~g}$ of content), while the excess over the control was proved in all test groups $(\mathrm{p}<0.01)$, except for the one that got $\mathrm{Zn}$ sulfate in the dose of $50 \mathrm{~g} / \mathrm{t}$. In terms of productivity, the most effective dose came out to be $100 \mathrm{~g} / \mathrm{t}$ : this group showed better egg production capacity, egg weight and significantly improved feed conversion. In all experimental groups, regardless of the source of $\mathrm{Zn}$, the concentration of $\mathrm{Zn}$, total protein, albumin and globulin fractions were increased in the plasma of the layers. The quality of albumen (relative mass, thickness, Haugh index) also improved.

A series of experiments [75] on 19-60 weeks old layers of the Bovans (White Leghorn) cross, having compared the effect of $\mathrm{Zn}$ sulfate and the organic preparation Availa-Zn (Zinpro, USA) in doses of 40, 80 and $120 \mathrm{~g} / \mathrm{t}$, did not justify significant influence on feed intake, egg production capacity, feed conversion, bogy weight gain, egg weight, relative shell weight, bone strength, and keel bone fractures rate. A dose of $80 \mathrm{~g} / \mathrm{t}$ in both forms increased the eggshell strength $(p<0.05)$. The organic form increased the relative weight of the yolk $(p<0.05)$ more effectively compared with the same dose of sulphate. The best coat condition was in birds that received $80 \mathrm{~g} / \mathrm{t}$ of sulphate, the worst one - in case of feeding $120 \mathrm{~g} / \mathrm{t}$ of the organic form. Fecal excretion of $\mathrm{Zn}$ increased in proportion to its dose in the diet and regardless of its form. A regression equation linking $\mathrm{Zn}$ concentrations in the diet and litter $\left(\mathrm{p}<0.0001, \mathrm{R}^{2}=0.78\right)$ was derived as follows: $\mathrm{Zn}_{\mathrm{d}}, \mathrm{g} / \mathrm{t}=-70.057+3.706 \times \mathrm{Zn}_{1}, \mathrm{~g} / \mathrm{t}$. The positive effect of zinc for laying hens in case of thermal [51] and cold stresses [76] and in protection against coccidiosis and eimeriosis [77] was reported. After feeding organic or inorganic $\mathrm{Zn}$ to layers, its maximum accumulation was $18 \mu \mathrm{g} / \mathrm{g}$ of egg content. 
In vitro bioavailability of $\mathrm{Zn}$ for humans was $75 \%$ in raw eggs, $69 \%$ in boiled eggs, and $65 \%$ in fried eggs [78]. It has been concluded that Zn-enriched eggs can provide up to $150 \%$ of the daily requirement of a year old children in this trace element.

A positive effect of combined organic forms of Se $(0.3 \mathrm{~g} / \mathrm{t})$ and $\mathrm{Zn}(60 \mathrm{~g} / \mathrm{t})$ in quails' diet on egg quality during storage $\left(4^{\circ} \mathrm{C}\right.$ or $\left.20^{\circ} \mathrm{C}\right)$ was reported [79]. Zn or $\mathrm{Zn}+\mathrm{Se}$ contributed to a better preservation of albumen compared to the control without additives or fed Se only. This combination looks promising, for $\mathrm{Zn}$ improves the quality and oxidation stability of albumen, Se - the same of yolk. However, selecting dosages and forms should be very careful, since there is antagonism between these trace elements due to competition for intestinal inhausting sites [80].

I od ine. This is one of the irreplaceable trace elements in human and animal nutrition. According to the World Health Organization, iodine deficiency is found in about $30 \%$ of the world's population (over 2 billion people). At the same time, 655 million have thyroid gland hypertrophy, and over 50 million suffer from mental disorders caused by iodine deficiency in their mother's diets [81]. In Russia, $75 \%$ of the population has its deficiency, manifested to a varying degree [82]. Many countries approved iodine deficiency prevention programs that use iodized salt and iodized food products - bread, milk and eggs [83]. Iodine is a part of thyroid hormones - thyroxine and its derivatives. They regulate metabolism (particularly the cellular oxidation processes) and significantly affect the growth and productivity of poultry. Iodine deficiency in laying hens can interrupt metabolism, reduce egg production capacity, and cause hypertrophy of the thyroid gland [84]. Thyroid hormones participate in the function of the pituitary gland, responsible for birds' photosensitivity and puberty [85]. Thyroid hormones (T3 and T4), as well as iodide, accumulate in the ovary, resulting in iodine easily transferred to the oocysts [86]. Thus, when feeding layers with iodized feed, the concentration of iodine in the egg yolk is usually ten times higher than that in the albumen.

Iodine is absorbed in the stomach and small intestine, and hormone-like iodine compounds can enter the bloodstream without cleavage [87]. Inorganic iodine is absorbed mainly in the form of iodide. The availability of feed iodine depends not only on its form, but also on the composition of the diet. For example, goitrogenic anti-nutritional factors (thio- and cyanoglycosides, etc.) of some cruciferae (canola) and leguminous crops (soybean, lupine, pea) impair absorption and use of any form of iodine [88]. It is also known that the assimilation of feed I is affected by the content of K, Ca, Sr, F, and Co in the diet [89]. As far as iodine absorbed in the intestine is metabolized mainly by the thyroid gland and its hormones, the process of stabilizing iodine concentration in eggs when feeding layers with iodine-rich food takes some time.

Having fed layers with I in the form of iodinated yeast in doses of 1 and $2 \mathrm{mg} / \mathrm{kg}$ (control - without I supplement) [90], the first 3 weeks deposition of I in yolk and shell either remained the same or slightly increased in all groups. Between the weeks 3 and 6 it was almost twice lower than before the beginning of the experiment. From week 6 to 7 I deposition slightly increased, and after the 9th week it increased rapidly, reaching significantly higher proved values by the week 12 (for a dose of $2 \mathrm{mg} / \mathrm{kg}$ twice as high) compared with the original ones. Since the same dynamics were observed in the control group, it could be concluded that in laying hens it was associated with the adaptation of I metabolism to the egg-laying stage, but not to the doses of feed iodine. Another experiment [91] with different doses of iodine (from 0.45 to $13.0 \mathrm{mg} / \mathrm{kg}$ ), its concentration in eggs after 5 and 10 weeks of feeding was almost the same. However, this experiment did not involve young layers that started the egg laying, but the 
old ones (55 weeks old or older), which were at the peak of egg production. It is possible that their metabolism has quickly adapted to the intake of I with food, because at the beginning of the productive cycle they have already passed the maintenance phase of I concentration in eggs. In laying Hisex Brown after feeding I ( $3.5 \mathrm{mg} / \mathrm{kg}$ of feed) for 10 weeks, its deposition in the yolk was about $5 \mathrm{mg} / \mathrm{kg}$ in the first 3 weeks and $17-20 \mathrm{mg}$ in the next 7 weeks [92]. Another experiment (93) indicated that after 1 month of feeding the diet with $4.0 \mathrm{mg} / \mathrm{kg}$ of iodine, its content in eggs increased from $75.96 \mu \mathrm{g} / 100 \mathrm{~g}$ of egg content in the control to $184.5 \mu \mathrm{g} / 100 \mathrm{~g}$.

Iodine is fed to birds with food or water, most often in inorganic forms (potassium iodide or sodium iodide, potassium iodate or calcium iodate: anhydrous, monohydrate or hexahydrate one). However, inorganic sources are unstable for they are prone to oxidation and/or reduction. Moreover, I evaporates (note that iodates are more stable than iodides) when processing and storing mixed fodders and premixes; light and moisture accelerate the decomposition of salts and sublimation of free I. Iodine losses from iodized salt can start from $50 \%$ after 1 week of storage, from finished feed - up to $70 \%$ after 2 months of storage. The incompatibility of inorganic forms of I with the salts of certain trace elements (especially, copper) in premixes has been reported. Moreover, the released I can destroy vitamins and other biologically active substances [94]. It should be noted that the amount of iodine in the feed will be lower than expected: for example, for a calculated value of $5 \mathrm{mg} / \mathrm{kg}$, the analysis of the chemical composition of the feed revealed the actual amount of I of only $4.20 \mathrm{mg} / \mathrm{kg}$ [95]. Due to the instability and high reactivity of I compounds, a scatter of evaluation results is possible depending on the method of analysis. In most of the research on layers, the I content was determined either with the aid of ionselective electrodes, or spectrophotometrically using the classic Sandel-Kolthoff method [96].

A number of stabilized sources of feed iodine like iodinated yeast, seaweed (kelp, etc.), iodine casein, and iodized extruded soybean have been developed. Russia uses Monclavit-1 preparation (Orgpolmersintez LLC, St. Petersburg), an aqueous-polymer system with I as a complex of poly-N-vinyl amide cyclosulphonic iodide, which performs an additional function of the drinking system disinfectant [82]. Another one is Yoddar (Innbiotekh LLC, Moscow), a dry fodder preparation based on iodized casein of cow's milk (iodine casein) [94]. Ukraine developed a liquid thermostable concentrate of iodine (Jodis R\&D and manufacturing company, Kiev) that can be given with water or food [97]. Organic sources of iodine (for example, iodotyrosine, where I is bound covalently and can be cleaved almost exclusively enzymatically) are more stable. Despite the greater preservation of iodates in feeds and premixes if compared to iodides, at the same dose of I, the element was better absorbed and transferred to eggs from potassium iodide than from potassium iodate [88] or calcium iodate [95] when used in doses (for I) $1-5$ and $0.25-5.0 \mathrm{mg} / \mathrm{kg}$, respectively. Comparison of calcium iodate with iodized yeast [98] showed that organic iodine preparation is more effective. After feeding in a dose of $1 \mathrm{mg} / \mathrm{kg}$ of feed (for iodine) for 12 weeks in the form of iodate and I-yeast, the concentration of iodine was 58.0 and $104.5 \mu \mathrm{g} / 100 \mathrm{~g}$ of yolk $(\mathrm{p}<0.05)$, at initial indexes in the groups of 50.57 and $51.75 \mu \mathrm{g} / 100 \mathrm{~g}$ of yolk, respectively. Note that feeding I-yeast (at a dose of I $2 \mathrm{mg} / \mathrm{kg}$ ) resulted in the accumulation of the element in an amount of $110.5 \mu \mathrm{g} / 100 \mathrm{~g}$ of yolk. That is, only $6 \%$ more than at a dose of $1 \mathrm{mg} / \mathrm{kg}$. Perhaps, in case of higher content of organic and inorganic forms of iodine in feeds this comparison will produce different results. NRC recommendations [62] establish the requirement of growing and adult egg hens in iodine of 0.33 - 
$0.48 \mathrm{mg} / \mathrm{kg}$ of a diet. At the same time, the maximum allowable amount of iodine in the rations of laying hens in the European Union in 2005 was reduced from 10 to $5 \mathrm{mg} / \mathrm{kg}$ of feed at a humidity of $12 \%$ [99].

High doses of iodine are toxic to poultry and worsen its health and productivity. It was reported that a dose of iodine of $6.07 \mathrm{mg} / \mathrm{kg}$ in the form of calcium iodate in the diet of ISA Brown layers fed for 52 weeks of the production period slightly reduced the egg production capacity, egg mass and feed conversion if compared to a dose of $3.57 \mathrm{mg} / \mathrm{kg}$. The decrease of the relative mass of the yolk (to the egg mass), the albumen Hau index and the absolute weight of the eggshell was proved $(\mathrm{p}<0.05)$ [100]. Similar results were obtained in the experiment that compared doses of iodine of $0 ; 3 ; 6 ; 12$ and $24 \mathrm{mg} / \mathrm{kg}$ in the form of calcium iodate. These doses were fed to brown layers for 30 weeks. Doses of 12 and $24 \mathrm{mg} / \mathrm{kg}$ resulted in a decrease in the Hau index and in the relative mass of albumen, as well as in the deterioration of feed conversion. The doses of 3 and $6 \mathrm{mg} / \mathrm{kg}$ [101] were considered safe for laying hens' productivity and egg quality. In both experiments the content of iodine in yolk, albumen and egg increased in proportion to its dose in the diet.

The Egyptian researchers' experiment [102] with different contents of $I$ in the feed in the form of KI in the doses of $0.3 ; 0.6 ; 1.2 ; 2.4 ; 4.8$ and $9.6 \mathrm{mg} / \mathrm{kg}$ resulted in recognizing the dose of $2.4 \mathrm{mg} / \mathrm{kg}$ the most effective in affecting the productivity of chickens. The authors note that it allows obtaining iodinefunctional eggs that can satisfy $44 \%$ of the daily requirement for iodine in children aged 1-10. With the increase in the amount of iodine in the chickens' diets, it was proved that the concentration of hormones T3 and T4, phosphorus and alkaline phosphatase in the blood plasma increased, and the amount of calcium decreased. The authors associate this to the effect of increasing the concentrations of thyroid hormones on gonadotropin secretion. Previous studies reported that in rats hyperthyroidism induces hyperphosphatemia and hypocalcemia [103]. The experiment conducted in India [91] compared doses of iodine (calcium iodate) of 0.45 (control); 3.25; 6.50; 9.75 and $13.0 \mathrm{mg} / \mathrm{kg}$ according to the economic efficiency of enriched eggs production. Eggs were checked for iodine content after 5 and 10 weeks of layers' consumption of enriched diets. The iodine concentration in the egg increased with the increase in its dose. The lowest cost for feeding was recorded in the group receiving a dose of $6.50 \mathrm{mg} / \mathrm{kg}$. In the groups receiving $I$ in the amount of 3.25 and $9.75 \mathrm{mg} / \mathrm{kg}$, this indicator was not different from the control. According to the same authors [104], high doses of iodine $(9.75$ and $13.0 \mathrm{mg} / \mathrm{kg})$ significantly and reliably $(\mathrm{p}<0.05)$ reduced digestibility and the use of macronutrients in the diet. The doses of 3.25 and $6.50 \mathrm{mg} / \mathrm{kg}$ were considered to be the most effective ones. The experiment [105] that compared doses of iodine of $0 ; 5 ; 10 ; 15$ and $20 \mathrm{mg} / \mathrm{kg}$ of feed (calcium iodate) showed that a dose of $10 \mathrm{mg} / \mathrm{kg}$ had no adverse effect on the productivity indices of the layers. On the one hand, in this case, the minimum content of cholesterol in the yolk was reliably recorded $(p<0.05)$. On the other hand, the minimum relative mass of eggshell and the maximum egg breakage rate and eggs with soft shell were also recorded.

Another important aspect of enriching eggs with iodine is the stability of this element in eggs after cooking. Previous research reported that after boiling the eggs, iodine of the albumen is usually destroyed, while the I concentration in the yolk decreases averagely by $10 \%$ [106]. However, other authors [91] did not note significant differences in the content of iodine in raw and boiled eggs. Iodine accumulates not only in the egg contents, but also in its shell, where being enriched with iodine, its deposition into the eggshell may exceed its deposition in yolk by an order of magnitude greater [90]. The growing interest in eggshell 
preparations as a source of trace elements in human nutrition (including Russia) [107] may promote using iodized eggshell for their production.

Since the absorption mechanisms of selenium and iodine are different, their high content in the diet does not interfere with the absorption and assimilation of both trace elements, which allows them to simultaneously enrich eggs. In rats, it was found that high intake of feed iodine against a background of selenium deficiency leads to an increase in oxidative damage to thyroid tissues due to a decrease in the activity of the thyroid gland. At the same time, relatively moderate doses of $\mathrm{Se}$ on the background of iodine deficiency compensate for a decrease in T4 concentration in the blood plasma [108]. The series of experiments conducted by Russian and Belorussian scientists, it was found that the inclusion of iodine organic compounds (kelp, I $-0.90 \mathrm{mg} / \mathrm{kg}$ ) and selenium (mixed SeMet and SeCys, Se $-0.29 \mathrm{mg} / \mathrm{kg}$ ) allows receiving enriched eggs without negative consequences for the productivity of laying hens and the quality of eggs [109, 110]. A decrease in MDA content in the layers' blood during week 15 of life and an improvement in other parameters of the body antioxidant status were recorded. Ukraine produces a version of the Yodis preparation (a dose of active iodine is $80 \mathrm{mg} / \mathrm{l})$, additionally enriched with Se as a citrate $(0.05 \mathrm{mg} / \mathrm{l})$.

Thus, it makes most sense to enrich diets of layers and, consequently, eggs with selenium and vitamin E, since this combination of the two most active feed antioxidants provides the best protection of the chickens and the high antioxidant status of eggs. The organic forms of Se are the most effective. They are better transferred to the egg and allow the creation of selenium repository in the body, which is mobilized in case of oxidative stress. This combination also ensures the maximum preservation of polyunsaturated fatty acids in egg yolk lipids. The optimal ratio of these two antioxidants in the layers diets is still to be determined. It would possibly be determined by the type and composition of the diet and housing conditions, as well as by the cost of the preparations used. Enrichment of eggs with zinc, when introduced into laying hens diets, enhances the quality and preservation of albumen, improves the condition of the eggshell, skeleton and coat, and have positive effect on the immunity of the layers. Inorganic sources of $\mathrm{Zn}$ can be introduced into diets at a dose of 50-80 g/t, organic ones at a dose of 50-100 g/t without reducing productivity. The combined egg enrichment with Se and $\mathrm{Zn}$ through feed is still unpromising due to the antagonism between these trace elements, which, perhaps, will be overcome with time by developing and investigating the interaction of new feed forms of elements. Increasing the iodine content in the layers' diets up to $5 \mathrm{mg} / \mathrm{kg}$, it is possible to obtain an egg, functional for this element. As some authors state, doses of $5-10 \mathrm{mg} / \mathrm{kg}$ also do not adversely affect the productivity, but lead to a certain decrease in the quality of eggs (eggshell thickness and strength, relative mass of albumen, Haugh index). The combined enrichment of eggs with iodine and Se is possible because there is no antagonism between these trace elements for absorption, but there is a certain metabolic synergy. However, the effectiveness of using different sources of these elements in diets requires further research.

\section{REFEREN C ES}

1. Kavtarashvili A.Sh., Ste fanova I.L., Svitkin V.S., Novotorov E.N. Functional egg production. I. The role of $\omega-3$ polyunsaturated fatty acids (review). Sel'skokhozyaistvennaya biologiya [Agricultural Biology], 2017, 2: 349-366 (doi: 10.15389/agrobiology.2017.2.349eng).

2. F i s i n i n V., S u ra i P., P a p a z y a $\mathrm{n}$ T. Zhivotnovodstvo Rossii, 2008, 1: 57-61 (in Russ.).

3. Surai P.F., Fis in in V.I. Natural antioxidants in hens' embryogenesis and antistress defense in postnatal development (review). Sel'skokhozyaistvennaya biologiya [Agricultural Biology], 2013, 2: 3-18 (doi: 10.15389/agrobiology.2013.2.3eng).

4. Mangiapane E., Pessione A., Pessione E. Selenium and selenoproteins: An over- 
view on different biological systems. Curr. Protein Rept. Sci., 2014, 15: 598-607 (doi: $10.2174 / 1389203715666140608151134)$.

5. Carlson B.A., Le e B.J., Tsuji P.A., Tobe R., Park J.M., Schweizer U., G la d y s hev V.N., H at fi e ld D.L. Selenocysteine tRNA[Ser]Sec: From nonsense suppressor tRNA to the quintessential constituent in seleprotein biosynthesis. In: Selenium: its molecular biology and role in human health. D.L. Hatfield, U. Schweizer, P.A. Tsuji, V.N. Gladyshev (eds.). Springer, 2016: 3-12 (doi: 10.1007/978-3-319-41283-2_1).

6. G a o H., Li u C.P., S ong S.Q., F u J. Effects of dietary selenium against lead toxicity on mRNA levels of 25 selenoprotein genes in the cartilage tissue of broiler chicken. Biol. Trace Elem. Res., 2016, 172(1): 234-241 (doi: 10.1007/s12011-015-0579-x).

7. N a s rtdinov R.G., A ndre eva A.V. V sbornike: Sovremennye dostizheniya veterinarnoi meditsiny $i$ biotekhnologii $-v$ sel'skokhozyaistvennoe proizvodstvo [Practical application of recent achievements of veterinary medicine and biocenology]. Ufa, 2009: 94-95 (in Russ.).

8. Chu F.F. Doroshow J.H., Esworthy R.S. Expression, characterization and tissue distribution of a new cellular selenium-dependent glutathione peroxidase, GSHPX-GI. J. Biol. Chem., 1993, 268(4): 2571-2576.

9. U rs in i F., He i m S., K i e s s M. Dual function of the selenoprotein PHGPx during sperm maturation. Science, 1999, 285(5432): 1393-1396 (doi: 10.1126/science.285.5432.1393).

10. Pappas A.C., Aca movic T., S parks N.H.C., Surai P.F., McDevitt R.M. Effects of supplementing broiler breeder diets with organic Se and polyunsaturated fatty acids on egg quality. Poultry Sci., 2005, 84(6): 865-874 (doi: 10.1093/ps/84.6.865).

11. Mohiti-Asli M., Shariatmadari F., Lotfollahian H., Mazuji M.T. Effects of supplementing layer hen diets with Se and vitamin E on egg quality, lipid oxidation and fatty acid composition during storage. Can. J. Anim. Sci., 2008, 88(3): 475-483 (doi: 10.4141/CJAS07102).

12. Wang Z.G., Pan X.J., Zhang W.Q., Peng Z.Q., Z hao R.Q., Z hou G.H. Methionine and Se yeast supplementation of the maternal diets affects antioxidant activity of breeding eggs. Poultry Sci., 2010, 89(5): 931-937 (doi: 10.3382/ps.2009-00268).

13. S u r a i P.F., Fis i n i n V.I. Selenium in livestock and other domestic animals. In: Selenium: its molecular biology and role in human health. D.L. Hatfield, U. Schweizer, P.A. Tsuji, V.N. Gladyshev (eds.). Springer, 2016: 595-606 (doi: 10.1007/978-3-319-41283-2_50).

14. Gulyus hi n S.Yu., Kovalev V.O. State of antiradical protection system in broilers during use of selenium containing preparations on the background of toxic feed (review). Sel'skokhozyaistvennaya biologiya [Agricultural Biology], 2009, 4: 14-25 (in Russ.).

15. B a rt holo m ew A., Lat shaw D., Sway n D.E. Changes in blood chemistry, hematology, and histology caused by a selenium/vitamin E deficiency and recovery in chicks. Biol. Trace Elem. Res., 1998, 62(1): 7-16 (doi: 10.1007/BF02820016).

16. Co m b s G.F., H a d y M.M. Selenium involved with vitamin E in preventing encephalomalacia in the chick. FASEB J., 1991, 5(4): A714.

17. Combs G.F. Clinical implications of selenium and vitamin E in poultry nutrition. Vet. Clin. Nutr., 1994, 1: 133-140.

18. Soffietti M.G., Nebbia C., Valenza F. Chronic experimental toxicity of cystine selenate in fowls. Clinical and pathological findings. Note I. Clin. Vet., 1983, 106(5): 97-106.

19. Kha n M.Z., S z e re k J., Marki e wi c z K. Effects of oral administration of toxic levels of lead and selenium upon concentration of different elements in the liver of broiler chicks. Zentralbl. Veterinarmed. A, 1993, 40(9-10): 652-664 (doi: 10.1111/j.1439-0442.1993.tb00681.x).

20. Q i Z.Y., H a n B., Q i n S., H o u J.W., D ong Q.A., Z h a ng B.X., Li u B.F. The studies of experimental organic selenium toxicosis in growing chickens. Acta Vet. Zootech. Sinica, 1992, 123: 281-284.

21. Salyi G., Banhidi G., Szabo E., Gonye S., Ratz F. Acute selenium poisoning in broilers. Magyar Állatorvosok Lapja, 1993, 48: 22-26.

22. T is h k o v A.I., V o it o v L.I. Veterinariya, 1989, 11: 65-67 (in Russ.).

23. Akulov V.A., Minina L.A., Andreev M.N., Tomskikh Yu.I., Bronnikov a K.A., Kore n kov I.P. Sel'skokhozyaistvennaya biologiya [Agricultural Biology], 1972, 3: 430-436 (in Russ.).

24. Z e ng H., Ca o J.J., C o mbs G.F. Jr. Selenium in bone health: roles in antioxidant protection and cell proliferation. Nutrients, 2013, 5(1): 97-110 (doi: 10.3390/nu5010097).

25. S u ra i P.F. Selenium in poultry nutrition 1. Antioxidant properties, deficiency and toxicity. World's Poultry Sci. J., 2002, 58(3): 333-347 (doi: 10.1079/WPS20020026).

26. C e li P., S e lle P.H., C ow i e s o n A.J. Effects of organic selenium supplementation on growth performance, nutrient utilization, oxidative stress and selenium tissue concentrations in broiler chickens. Anim. Prod. Sci., 2014, 54: 966-971 (doi: 10.1071/AN13116).

27. Karpova E.A., D e mide n ko O.K., I l'i n a O.P. Vestnik KrasGAU, 2014, 4: 207-210 (in Russ.).

28. Radwan N.L., S a lah Eldin T.A., E l- Z a i a t A.A., Mos ta fa A.S.A. Effects of die- 
tary nano-selenium supplementation on selenium content and oxidative stability in table eggs and productive performance of laying hens. Int. J. Poultry Sci., 2015, 14(3): 161-176 (doi: 10.3923/ijps.2015.161.176).

29. Mohapatra P., Swain R.K., M is hra S.K., B e he ra T., Swain P., M is hra S.S., B e hura N.C., Sabat S.C., S ethy K., D ham a K., J a y a s n a r P. Effects of dietary nano-selenium on tissue selenium deposition, antioxidant status and immune functions in layer chicks. Int. J. Pharmac., 2014, 10(3): 160-167 (doi: 10.3923/ijp.2014.160.167).

30. S u nde R.A., H o e k s tra W.G. Incorporation of selenium from selenite and selenocystine into glutathione peroxidase in the isolated perfused rat liver. Biochem. Biophys. Res. Commun., 1980, 93(4): 1181-1188 (doi: 10.1016/0006-291X(80)90614-2).

31. G a lo chki n V.A., G a lo chk i n a V.P. Organic and mineral forms of selenium, their metabolism, biological availability and role. Sel'skokhozyaistvennaya biologiya [Agricultural Biology], 2011, 4: 3-15 (in Russ.)

32. Shini S., Sultan A., Bryden W.L. Selenium biochemistry and bioavailability: Implications for animal agriculture. Agriculture, 2015, 5(4): 1277-1288 (doi: 10.3390/agriculture5041277).

33. B e hne D., Kyriacopoulos A. Mammalian selenium-containing proteins. An. Rev. Nutr., 2001, 21: 453-473 (doi: 10.1146/annurev.nutr.21.1.453).

34. Bierla K., Dernovics M., Vacchina V., Szpunar J., Bertin G., Lobins k i R. Determination of selenocysteine and selenomethionine in edible animal tissues by 2D size-exclusion reversed-phase HPLC-ICP MS following carbamidomethylation and proteolytic extraction. Anal. Bioanal. Chem., 2008, 390(7): 1789-1798 (doi: 10.1007/s00216-008-1883-5).

35. Wolff r a m S. Absorption and metabolism of selenium: Difference between organic and inorganic sources. In: Biotechnology in the feed industry. T.P. Lyons, K.A. Jacques (eds.). Nottingham Univ. Press, Nottingham, UK, 1999: 547-566.

36. Drevko B.I., Antipov V.A., Zhukov O.I., Fomenko L.A., Markova L.I., Drevko R.I., Rodi o nova T.N., Efre mov V.I., Kha r c he n k V.G. Sredstvo dlya lecheniya $i$ profilaktiki boleznei, vyzyvaemykh nedostatochnost'yu selena $v$ organizme sel'skokhozyaistvennykh zhivotnykh $i$ ptits. Patent RU 2051681. Zayavka № 93045743/15, 1993. Opubl. 10.01.1996. Byul. № 1 [A medicine to treat and protect farm animals and poultry against diseases caused by selenium deficit. Patent RU 2051681. Appl. № 93045743/15, 1993. Publ. January 10, 1996. Bul. № 1] (in Russ.).

37. Papazyan T.T., F is i $n$ i n V.I., S u r a i P.F. Ptitsa i ptitseprodukty, 2009, 2: 21-24 (in Russ.).

38. Papazyan T.T., F is i n i n V.I., S u r a i P.F. Ptitsa i ptitseprodukty, 2009, 1: 37-39 (in Russ.).

39. S křiva n M., M a rou nek M., D lou há G., S evcík ová S. Dietary selenium increases vitamin E contents of egg yolk and chicken meat. Br. Poultry Sci., 2008, 49(4): $482-486$ (doi: 10.1080/00071660802236021).

40. Ti w ary A.K., S te g e $1 \mathrm{~m}$ e i e r B.L., P a nte r K.E., J a m e s L.F., H all J.O. Comparative toxicosis of sodium selenite and selenomethionine in lambs. J. Vet. Diagn. Invest., 2006, 18: 61-70 (doi: 10.1177/104063870601800108).

41. Zduńczyk Z., Drażbo A., Jankowski J., Juśkiewicz J., Czech A., Antos z ki e w i c z Z. The effect of different dietary levels of vitamin E and selenium on antioxidant status and immunological markers in serum of laying hens. Polish J. Vet. Sci., 2013, 16(2): 333-339 (doi: 10.2478/pjvs-2013-0045).

42. Iqbal R., Aziz T., Sarfaraz I., Shabir R., Ansari M.S., Malik M.F., $\mathrm{S}$ a le e m R., Z a h r a A., M e hw is h S. Effect of vitamin E and selenium on immunity, egg production and liver function in laying hens. Middle-East J. Sci. Res., 2013, 14(9): 1165-1170.

43. Jing C.L., Dong X.F., Wang Z.M., Liu S., Tong J.M. Comparative study of DLselenomethionine vs sodium selenite and seleno-yeast on antioxidant activity and selenium status in laying hens. Poultry Sci., 2015, 94(5): 965-975 (doi: 10.3382/ps/pev045).

44. Alja mal A.A., Purdu m S.E., H a n ford K.J. The effect of normal and excessive supplementation of selenomethionine and sodium selenite in laying hens. Intl. J. Appl. Poultry Res., 2014, 3(3): 33-38.

45. Kavtarashvili A.SH., Novotorov E.N., Stefanova I.L., Svitkin V.S. Ptitsevodstvo, 2017, 2: 6-10 (in Russ.).

46. Fasiangova M., B orilova G. Impact of Se supplementation on the oxidation stability of eggs. World's Poultry Sci. J., 2017, 73(1): 175-184 (doi: 10.1017/S0043933916000854).

47. S cheidele r S.E., Weber P., Mo nsalve D. Supplemental vitamin E and selenium effects on egg production, egg quality, and egg deposition of $\alpha$-tocopherol and selenium. $J$. Appl. Poultry Res., 2010, 19: 354-360 (doi: 10.3382/japr.2010-00198).

48. Mohiti-Asli M., Shariatmadari F., Lotfollahian H. The influence of dietary vitamin $\mathrm{E}$ and selenium on egg production parameters, serum and yolk cholesterol and antibody response of laying hens exposed to high environmental temperature. Arch. Geflügelk., 2010, 74(1): 43-50.

49. S křivan M., B ubancová I., M a rounek M., D louhá G. Selenium and $\alpha-$ tocopherol content in eggs produced by hens that were fed diets supplemented with selenomethionine, sodium selenite and vitamin E. Czech J. Anim. Sci., 2010, 55(9): 388-397.

50. M a r e t W. Zinc biochemistry: From a single zinc enzyme to a key element of life. Adv. Nutr., 
2013, 4(1): 82-91 (doi: 10.3945/an.112.003038).

51. Sahin K., Sahin N., Kucuk O., Hayirli A., Pras ad A.S. Role of dietary zinc in heatstressed poultry: A review. Poultry Sci., 2009, 88(10): 2176-2183 (doi: 10.3382/ps.2008-00560).

52. Niles B.J., Clegg M.S., Hanna L.A., Chou S.S., Momma T.Y., Hong H., $\mathrm{K}$ e e n C.L. Zinc deficiency-induced iron accumulation, a consequence of alterations in iron regulatory protein-binding activity, iron transporters and iron storage proteins. J. Biol. Chem., 2008, 283(8): 5168-5177 (doi: 10.1074/jbc.M709043200).

53. Washabaugh M.W., Collins K.D. Dihydroorotase from Escherichia coli. Sulfhydryl group metal ion interactions. J. Biol. Chem., 1986, 261(13): 5920-5929.

54. Tse-Dinh Y.C., Beran-Steed R.K. Escherichia coli DNA topoisomerase I is a zinc metalloprotein with three repetitive zinc-binding domains. J. Biol. Chem., 1988, 263(31): 15857-15859.

55. Fu H.W., Moomaw J.F., Moomaw C.R., C a s e y P.J. Identification of a cysteine residue essential for activity of protein farnesyltransferase. Cys299 is exposed only upon removal of zinc from the enzyme. J. Biol. Chem., 1996, 271(45): 28541-28548 (doi: 10.1074/jbc.271.45.28541).

56. Oteiza P.L., Olin K.L., F r a g a C.G., K e e n C.L. Oxidant defense systems in testes from zinc deficient rats. Proc. Soc. Experim. Biol. Med., 1996, 213(1): 85-91 (doi: 10.3181/00379727213-44040).

57. Kidd M.T., Ferket P.R., Qureshi M.A. Zinc metabolism with special reference to its role in immunity. World's Poultry Sci. J., 1996, 52(3): 309-324 (doi: 10.1079/WPS19960022).

58. Unde rwo od E.J. The mineral nutrition of livestock. Commonwealth Agriculture Bureau, Slough, UK, 1981.

59. D e wa r W.A., Wight P.A.L., P e a rs o n R.A., G e n t le M.J. Toxic effects of high concentrations of zinc oxide in the diet of the chick and laying hen. Brit. Poultry Sci., 1983, 24(3): 397-404 (doi: 10.1080/00071668308416754).

60. G i o r d a n o P.M., M o r t v e d t J.J., M a y s D.A. Effect of municipal wastes on crop yields and uptake of heavy metals. J. Environ. Qual., 1975, 4: 349-399 (doi: 10.2134/jeq1975.00472425000400030024x).

61. Kim W.K., P a t t e rs o n P.H. Effects of dietary zinc supplementation on broiler performance and nitrogen loss from manure. Poultry Sci., 2004, 83(1): 34-38 (doi: 10.1093/ps/83.1.34).

62. NRC. Nutrient requirements of poultry. $9^{\text {th }}$ Ed. National Academic Press, Washington, D.C., 1994.

63. A o T., Pierce J.L., P es catore A.J., C antor A.H., D aw son K.A., Ford M.J., $\mathrm{S} h$ af e $\mathrm{r}$ B.L. Effects of organic zinc and phytase supplementation in a maize-soybean meal diet on the performance and tissue zinc content of broiler chicks. Br. Poultry Sci., 2007, 48(6): 690-695 (doi: 10.1080/00071660701694072).

64. S a 1 i m H.M., J o C., L e e B.D. Zinc in broiler feeding and nutrition. Avian Biol. Res., 2008, 1(1): 5-18 (doi: 10.3184/175815508X334578).

65. Star L., van der Klis J.D., Rapp C., Ward T.L. Bioavailability of organic and inorganic zinc sources in male broilers. Poultry Sci., 2012, 91(12): 3115-3120 (doi: 10.3382/ps.2012-02314).

66. S a li m H.M., L e e H.R., J o C., Le e S.K., Le e B.D. Effect of sources and levels of zinc on the tissue mineral concentration and carcass quality of broilers. Avian Biol. Res., 2010, 3(1): 23-29 (doi: 10.3184/175815510X12636595095213).

67. Pimentel J.L., Cook M.E., Greger J.L. Research note: Bioavailability of zincmethionine for chicks. Poultry Sci., 1991, 70(7): 1637-1639 (doi: 10.3382/ps.0701637).

68. Ca o J., He n ry P.R., Guo R., Holwerda R.A., Toth J.P., Lit te 11 R.C., Mile s R.D., A $\mathrm{m} \mathrm{m}$ e $\mathrm{r} \mathrm{m}$ a $\mathrm{n}$ C.B. Chemical characteristics and relative bioavailability of supplemental organic zinc sources for poultry and ruminants. J. Anim. Sci., 2000, 78(8): 2039-2054 (doi: $10.2527 / 2000.7882039 x$ ).

69. Burrell A.L., D oz i e r W.A., D avis A.J., C o m p to n M.M., Fre e man M.E., Ve nd re 11 P.F., W a rd T.L. Responses of broilers to dietary zinc concentrations and sources in relation to environmental implications. Br. Poultry Sci., 2004, 45(2): 225-263 (doi: 10.1080/00071660410001715867).

70. Hud s o n B.P., D o z i e r W.A., Wi l s o n J.L., S a nd e r J.E., Wa rd T.L. Reproductive performance and immune status of caged broiler breeder hens provided diets supplemented with either inorganic or organic sources of zinc from hatching to $65 \mathrm{wk}$ of age. J. Appl. Poult. Res., 2004, 13(2): 349-359 (doi: 10.1093/japr/13.2.349).

71. Aliarabi H., Ahmadi S.A., Hosseini-Siyar M.M., Tabatabie A., Saki K.H., A s h ori N. Effect of different level and sources of zinc on egg quality and layer performance. Proc. Aust. Poultry Sci. Symp., 2007, 19: 102-105.

72. Stefane 11 o C., S a n tos T.C., Muraka mi A.E., Martins E.N., Carneiro T.C. Productive performance, eggshell quality, and eggshell ultrastructure of laying hens fed diets supplemented with organic trace minerals. Poultry Sci., 2014, 93(1): 104-113 (doi: 10.3382/ps.2013-03190).

73. M a nangi M.K., Vazques-A non M., Richards J.D., Carter S., Knight C.D. The impact of feeding supplemental chelated trace minerals on shell quality, tibia breaking strength, and immune response in laying hens. J. Appl. Poult. Res., 2015, 24(3): 316-326 (doi: 
$10.3382 / \mathrm{japr} / \mathrm{pfv} 029)$.

74. B ahakaim A.S.A., Abde $1 \mathrm{Magied}$ H.A., Osman S.M.H., O mar A.S., Abde 1 M a lak N.Y., R a mad a n N.A. Effect of using different levels and sources of zinc in layer's diets on egg zinc enrichment. Egypt. Poultry Sci., 2014, 34(1): 39-56.

75. M a rtin K.M. The effects of zinc supplementation from two sources on egg quality and bone health in laying hens. PhD Thes. Lincoln, Univ. of Nebraska, 2016.

76. Onderci M., Sahin N., Sahin K., Kilic N. Antioxidant properties of chromium and zinc: in vivo effects on digestibility, lipid peroxidation, antioxidant vitamins, and some minerals under a low ambient temperature. Biol. Trace Elem. Res., 2003, 92(2): 139-150 (doi: 10.1385/BTER:92:2:139).

77. B u n S.D., G u o Y.M., G u o F.C., J i F.J., C a o H. Influence of organic zinc supplementation on the antioxidant status and immune responses of broilers challenged with Eimeria tenella. Poultry Sci., 2011, 90(6): 1220-1226 (doi: 10.3382/ps.2010-01308).

78. Plaimast H., Sirichakwal P.P., Puwastien P., Judprasong K., Wasantwis ut E. In vitro bioaccessibility of intrinsically zinc-enriched egg and effect of cooking. $J$. Food Compos. Anal., 2009, 22(7-8): 627-631 (doi: 10.1016/j.jfca.2009.04.007).

79. Fernandez I.B., Cruz V.C., Poly carpo G.V. Effect of dietary organic selenium and zinc on the internal egg quality of quail eggs for different periods and under different temperatures. Rev. Bras. Cienc. Avic., 2011, 13(1): 35-41 (doi: 10.1590/S1516-635X2011000100006).

80. Hou se W.A., We $1 \mathrm{ch}$ R.M. Bioavailability of and interactions between zinc and selenium in rats fed wheat grain intrinsically labeled with ${ }^{65} \mathrm{Zn}$ and ${ }^{75} \mathrm{Se}$. J. Nutr., 1989, 119(6): 916-921.

81. Hetzel B., Mano M.T. A review of experimental studies of iodine deficiency during fetal development. J. Nutr., 1989, 119(2): 145-152.

82. S piridonov A., Kislova O. Ptitsevodstvo, 2011, 3: 21-25 (in Russ.).

83. Flynn A., Moreiras O., Stehle P., Fletcher R.J., Mueller D.J.G., Rol1 a nd V. Vitamins and minerals: a model for safe addition to foods. Eur. J. Nutr., 2003, 42(2): 118-130 (doi: 10.1007/s00394-003-0391-9).

84. L e w i s P.D. Responses of domestic fowl to excess iodine: a review. Brit. J. Nutr., 2004, 91(1): 29-39 (doi: 10.1079/BJN20031017).

85. Proudman J.A., S i opes T.D. Relative and absolute photorefractoriness in turkey hens: profiles of prolactin, thyroxine, and triiodothyronine early in the reproductive cycle. Poultry Sci., 2002, 81 (8): 1218-1223 (doi: 10.1093/ps/81.8.1218).

86. We ntworth B.C., Ringer R.K. Thyroids. In: Avian physiology. P.D. Sturkie (ed.). Springer Verlag, 2012: 453.

87. Podobed L.I., S te p a n e n ko A.N., Kap i to nova E.A. Rukovodstvo po mineral'nomu pitaniyu sel'skokhozyaistvennoi ptitsy [Mineral nutrition in piultry - recommendations]. Odessa, 2016 (in Russ.).

88. Słupczynska M., Jamroz D., Orda J., Wiliczkiewicz A. Effect of various sources and levels of iodine, as well as the kind of diet, on the performance of young laying hens, iodine accumulation in eggs, egg characteristics, and morphotic and biochemical indices in blood. Poultry Sci., 2014, 93(10): 2536-2547 (doi: 10.3382/ps.2014-03959).

89. D raganov I.F., Fis in in V.I., Ka lashnikov V.V., U shakov A.S. Mineral'noe pitanie zhivotnykh [Mineral nutrition of animals]. Moscow, 2012 (in Russ.).

90. Dolińska B., Opaliński S., Zieliński M., Chojnacka K., Dobrzański Z., R y z z a F. Iodine concentration in fodder influences the dynamics of iodine levels in hen's egg components. Biol. Trace Elem. Res., 2011, 144(1-3): 747-752 (doi: 10.1007/s12011-011-9147-1).

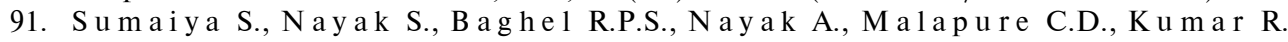
Effect of dietary iodine on production of iodine enriched eggs. Vet. World, 2016, 9(6): 554-558 (doi: 10.14202/vetworld.2016.554-558).

92. Kroupova V., Travnicek J., Kursa J., Kratochvil P., Krabacova I. Iodine content in egg yolk during excessive intake by laying hens. Czech J. Anim. Sci., 1999, 44: 369-376.

93. Charoensiriwatana W., Srijantr P., Tecyapant P., Wongvilairattana J. Consuming iodine enriched eggs to solve the iodine deficiency endemic for remote areas in Thailand. Nutr. J., 2010, 9: 68 (doi: 10.1186/1475-2891-9-68).

94. Fisinin V.I., Egorov I.A., Egorova T.V., Rozanov B.L., Yudin S.M. Ptitsa $i$ ptitseprodukty, 2011, 4: 37-40 (in Russ.).

95. Rottger A.S., Halle I., Wagner H., Breves G., Danicke S., Flachowsk y G. The effects of iodine level and source on iodine carry-over in eggs and body tissues of laying hens. Arch. Anim. Nutr., 2012, 66(5): 385-401 (doi: 10.1080/1745039X.2012.719795).

96. S h e lo r C.P., D a s g u t a P.K. Review of analytical methods for the quantification of iodine in complex matrices. Anal. Chim. Acta, 2011, 702(1): 16-36 (doi: 10.1016/j.aca.2011.05.039).

97. Miskiniene M., Kepaliene I., Bobinene R., Gudaviciute D., Eider J. Application of «Jodis» as a stable source of iodine in the nutrition of laying hens. Bull. Vet. Inst. Pulawy, 2010, 54: 389-392.

98. Opaliński S., Dolińska B., Korczyński M., Chojnacka K., Dobrzański Z., Ryszka F. Effect of iodine-enriched yeast supplementation of diet on performance 
of laying hens, egg traits, and egg iodine content. Poultry Sci., 2012, 91(7): 1627-1632 (doi: 10.3382/ps.2011-02031).

99. EU Commission. Commission Regulation (EC) No 1459/2005 amending the conditions for authorization of a number of feed additives belonging to the group of trace elements. Off. $J$. Eur. Union, 2005: L 233/8-233/10.

100. Lichovnikova M., Zeman L., Cermakova M. The long-term effects of using a higher amount of iodine supplement on the efficiency of laying hens. Brit. Poultry Sci., 2003, 44(5): $732-734$ (doi: 10.1080/00071660310001643741).

101. Yalçi n S., Kahraman Z., Yalçin S., Yalçi n S.S., Dedeoğlu H.E. Effects of supplementary iodine on the performance and egg traits of laying hens. Brit. Poultry Sci., 2004, 45(4): 499-503 (doi: 10.1080/00071660412331286208).

102. Abde l- M a lak N.Y., O s m a n S.M.H., B a haka i m A.S.A., O ma r A.S., Ra ma $\mathrm{d}$ a $\mathrm{n}$ N.A. Effect of using different levels of iodine in layer's diets on egg iodine enrichment. Egypt. Poult. Sci., 2012, 32(4): 851-864.

103. S e rakides R., $\mathrm{Nu}$ es V.A., $\mathrm{N}$ a s cimento E.F., S ilva C.M., Ribe iro A.F.C. Relationship between thyroid gonads and plasmatic levels of phosphorus, calcium and alkaline phosphates in rats. Arq. Bras. Med. Vet. Zoot., 2000, 52(6): 579-585.

104. S u mai ya S., Nayak S., B aghe 1 R.P.S., Khare A., M a lapu re C.D., Kumar R. Performance and nutrient utilization in laying hens fed iodine supplemented diets. Ind. J. Anim. Nutr., 2016, 33(3): 326-330 (doi: 10.5958/2231-6744.2016.00057.8).

105. Saki A.A., Faris a r M.A., Alia rabi H., Zamani P., Abbas ine zhad M. Iodine enriched egg production in response to dietary iodine in laying hens. J. Agric. Technol., 2012, 8(4): $1255-1267$.

106. Oliva T.V., Gorshkov G.I. Sovremennye problemy nauki i obrazovaniya, 2014, 5: 612 (in Russ.).

107. K r a s n o y a r ts e v G.V. Otechestvennoe ptitsevodstvo - osnova lechebno-profilaktiche-skikh preparatov s primeneniem skorlupy yaits. Mat. XI Int. Sci. Pract. Conf. «Fundamental and Applied Science-2015». Sheffield (UK), 2015, 14: 77-81.

108. Hotz C.S., Fitzpatrick D.W., Trick K.D., L'Abbé M.R. Dietary iodine and selenium interact to affect thyroid hormone metabolism of rats. J. Nutr., 1997, 127(6): 1214-1218.

109. E g o ro v I., P o n o m a r e n k o Yu. Kombikorma, 2007, 3: 79-80 (in Russ.).

110. Po nomare nko Yu.A. Effect of high doses of iodine and selenium on the egg-laying capacity of hens and accumulation of these micronutrients in eggs. Rus. Agric. Sci., 2015, 41(4): 280-284 (doi: 10.3103/S1068367415040163). 